\title{
Methods for the recovery of nutrients and energy from swine manure. 1. Biogas
}

\author{
L. Boersma ${ }^{1}$, E. Gasper ${ }^{1}$, J. E. Oldfield ${ }^{2}$ and P. R. Cheeke ${ }^{2}$ \\ ${ }^{1}$ Department of Soil Science, Oregon State University, Corvallis, Oregon 97331, \\ USA \\ ${ }^{2}$ Department of Animal Science, Oregon State University, Corvallis, Oregon 97331, \\ USA
}

Accepted: 5 June 1980

Key words: anaerobic digester, biogas, energy recovery, swine manure.

\section{Summary}

The combustible energy content of the products involved in raising pigs from 50 to $100 \mathrm{~kg}$ is shown. The values are for a one-year period. Certain comparisons have been made. Energy values of the products are shown as a percentage of the total energy input, including the solar energy fixed by the grain and straw and the energy expended in the farming operations.

The nutrients in the manure represent energy that was expended in the mining and processing. Each time these nutrients are returned to the land, the equivalent amount of energy does not have to be expended and is therefore saved. The production of $\mathrm{N}, \mathrm{P}$, and $\mathrm{K}$ require $73.9,13.4$, and $9.2 \mathrm{MJ} / \mathrm{kg}$ respectively. The use of the minerals represents a saving of 105000,4200 , and $4200 \mathrm{MJ} /$ year respectively.

Interpretation of the data with respect to efficiency of energy use must be done with care. The efficiency of energy use is defined as the energy content of the product divided by the energy expended to produce the product. Difficulties arise when the energy inputs are not clearly defined. For example, the input of 108 units of cultural energy produces 894 units of energy in the form of grain and straw. The energy efficiency of farming is therefore 8.3 , or $830 \%$. On the other hand, the energy input of 619 units produces 59 units of pork for an energy efficiency of 0.09 , or $9 \%$. Discussions of energy efficiency can easily lead to misunderstanding and certainly to gross misinterpretation of facts.

The most significant conclusion of our analysis is that digestion of the manure can produce substantial amounts of energy. With straw added to the digester, the energy content of the biogas is $86.4 \%$ of the energy used on the farm for all farming activities. This is a clear indication that the potential exists to develop methods of operation which allow farms to become energy-independent. 


\section{Introduction}

Manure stinks! Special precautions must be taken in storing it. Discharge to surface waters causes eutrophication. Storage and treatment is a nuisance to the farmer because of the smell and the cost. Yet manure is also hailed as a valuable resource. It is a source of digestible organic material, plant nutrients, and protein. Many methods for the use of manure have been proposed. But few of these are now in use by farmers. We wanted to know why efforts to recover useful products from this seemingly valuable resource have not been more successful. We did so by obtaining energy and material balances of several methods for the management of swine manure. The methods, sometimes referred to as bioconversion, are based on the use of microorganisms to convert the manure into feed and biogas.

The cells of microorganisms such as algae, yeasts, microfungi or bacteria contain high-quality protein, often referred to as 'single cell protein' or SCP. This nomenclature avoids unpleasant conotations relative to food which might be associated with such terms as 'bacterial' or 'microbial'. In addition to their high protein content, the advantages of these organisms are the possibility of growing them during the entire year and the potential for technological management.

The solids in the manure consist of cellulose fibers, bacterial cells, spilled feed, hairs, and other debris. These materials can be broken down into methane $\left(\mathrm{CH}_{4}\right)$ and carbon dioxide $\left(\mathrm{CO}_{2}\right)$ by anaerobic microorganisms. Prominent among these are the methane bacteria.

The dissolved organic matter together with dissolved nitrogen $(\mathrm{N})$ can be used by yeast and microfungi as a source of food to produce cells rich in protein. The dissolved minerals can be used by algae, which use low-energy substrates together with the input of light energy, to produce cells rich in protein.

Successful implementation of bioconversion methods would have several benefits to society. Among these are improved efficiency of energy use and food production, elimination of pollution problems, recycling of raw materials, and conservation of non-renewable resources. The methods discussed here are combinations of bioconversion processes. We developed energy and material balances based on the feed energy needs and waste discharge of 100 pigs. The information presented in Fig. 1 is from our own measurements and experiences (Boersma et al., 1978) as well as from literature reports.

It is assumed that the pigs weigh initially $50 \mathrm{~kg}$ each and are fed to reach a final weight of $100 \mathrm{~kg}$. The gain in weight is $0.80 \mathrm{~kg}$ per pig per day and the ratio of gain/feed is 0.263 . The amount of feed consumed is therefore $3.04 \mathrm{~kg}$ per pig per day. Each pig discharges 3 liters of fresh manure per day containing $14 \%(\mathrm{w} / \mathrm{w})$ solids or $0.42 \mathrm{~kg}$. The duration of the feeding period is $50 / 0.80=62.5$ days.

\section{Feed}

For this report we assume a simplified ration of corn and soybean meal. In most rations other sources of protein and energy are substituted including barley, wheat, cottonseed meal, fish meal, alfalfa, or whey. Salts, vitamins, and antibiotics are also added. 


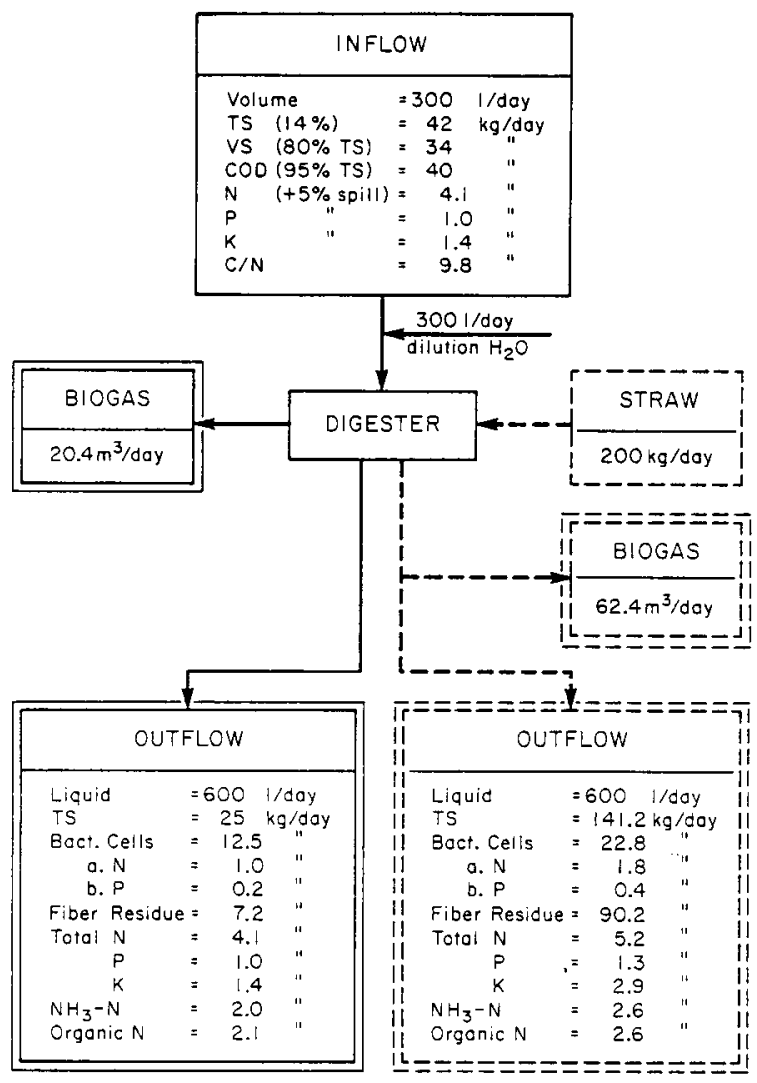

Fig. 1 Material balances for the manure discharged by 100 pigs, being fed to gain weight from 50 to 100 $\mathrm{kg}$ at the rate of $0.8 \mathrm{~kg} /$ day. The manure is routed to a digester for production of biogas. Similar balances are shown for a system of management where straw is added to the digester for increased gas yields.

The amount of feed for 100 pigs is $304 \mathrm{~kg} /$ day. It contains $12 \%$ or $36.5 \mathrm{~kg}$ crude protein of which $75 \%$ or $27.4 \mathrm{~kg}$ is contributed by the corn and $25 \%$ or $9.1 \mathrm{~kg}$ by the soybean meal. The feed contains $283.7 \mathrm{~kg}$ of corn with a protein content of $9.65 \%$ and $20.3 \mathrm{~kg}$ of soybean meal with a protein content of $45 \%$. The $\mathrm{N}$ content of the daily ration is $5.84 \mathrm{~kg} .{ }^{1}$

We assume $0.35 \%$ or $0.99 \mathrm{~kg}$ and $0.70 \%$ or $0.14 \mathrm{~kg}$ of phosphorus (P) in the corn and soybean meal, respectively, for a total of $1.13 \mathrm{~kg}$ in the daily ration. The corresponding values for potassium $(\mathrm{K})$ are $0.40 \%$ or $1.13 \mathrm{~kg}$ in the corn and $1.80 \%$ or $0.37 \mathrm{~kg}$ in the soybean meal for a total of $1.50 \mathrm{~kg}$. The 100 pigs gain a total of $80 \mathrm{~kg} /$ day. The added weight contains $2.56 \% \mathrm{~N}, 0.18 \% \mathrm{P}$, and $0.25 \% \mathrm{~K}$ on

These discussions are based on the assumption that the nitrogen content of protein is $16 \%$. 
a $w / w$ basis. The pigs therefore retain $2.05 \mathrm{~kg} \mathrm{~N}, 0.15 \mathrm{~kg} \mathrm{P}$, and $0.20 \mathrm{~kg} \mathrm{~K}$ per day or $35.1 \%$ of the $\mathrm{N}, 13.3 \%$ of the $\mathrm{P}$, and $13.3 \%$ of the $\mathrm{K}$ in the feed. By difference, $3.79 \mathrm{~kg} \mathrm{~N}, 0.98 \mathrm{~kg} \mathrm{P}$, and $1.30 \mathrm{~kg} \mathrm{~K}$ per day are discharged with the feces. In addition, we assume that $5 \%$ on the feed is spilled and added to the manure.

\section{Land area}

The land area needed for growing the feed can be estimated by assuming that consecutive groups of 100 pigs are fed throughout the year. This implies that $350 / 62.5=5.6$ groups of pigs are raised from 50 to $100 \mathrm{~kg}$, leaving 15 days for change between groups. The requirement for soybean meal is $20.3 \times 350=7105$ $\mathrm{kg} /$ year and for corn $283.7 \times 350=99295 \mathrm{~kg} /$ year. Assuming yields of 8000 $\mathrm{kg} / \mathrm{ha}$ per year for corn grain and $2490 \mathrm{~kg} / \mathrm{ha}$ per year for soybean meal (83\% of $3000 \mathrm{~kg} / \mathrm{ha}$ per year) the land areas required for growing the feed are 12.41 ha for corn and 2.85 ha for soybeans, or a total of $15.26 \mathrm{ha}$. The number of pigs fed during one year is 560 which corresponds to $36.7 \mathrm{pigs} / \mathrm{ha}$.

Left behind in the fields are the straw and stover which amount to $8000 \mathrm{~kg} / \mathrm{ha}$ per year for the corn or a total of $99280 \mathrm{~kg} /$ year and $3500 \mathrm{~kg} / \mathrm{ha}$ per year for the soybeans or a total of $9975 \mathrm{~kg}$ /year. The total amount of straw is $109255 \mathrm{~kg} /$ year. We assume that $75 \%$ of the straw or $81941 \mathrm{~kg} /$ year can be removed without detriment to the land. The root systems contain 5000 and $2000 \mathrm{~kg} / \mathrm{ha}$ per year for the corn and soybeans, respectively, for a total of $67750 \mathrm{~kg} /$ year.

\section{Energy requirements}

The amount of solar energy captured by the plants can be calculated by assuming a combustible energy content of $18.9 \mathrm{MJ} / \mathrm{kg}$ (Table 1). The assumption indicates that the corn captured $397000 \mathrm{MJ} /$ ha per year (grain $151000 \mathrm{MJ}$; stubble $151000 \mathrm{MJ}$; roots $95000 \mathrm{MJ}$ ) and the soybeans captured $160000 \mathrm{MJ} /$ ha per year (beans 56000 $\mathrm{MJ}$; stubble $66000 \mathrm{MJ}$; roots $38000 \mathrm{MJ}$ ). The total amount of solar energy captured is therefore $5400 \mathrm{GJ} /$ year (corn $4930 \mathrm{GJ}$; soybeans: $470 \mathrm{GJ}$ ). Farming operations, including labor, machinery, fuel, fertilizers, seeds for planting, insecticides, herbicides, irrigation, transportation, and drying require an estimated 30000 $\mathrm{MJ} /$ ha for a total of $455000 \mathrm{MJ} /$ year (Pimentel et al., 1974). About $50 \%$ of this is in the form of direct energy expenditure on the farm in the form of fuel and electricity, about $30 \%$ is for the mining and manufacturing of fertilizers, mainly nitrogen, and the remaining $20 \%$ is for labor, pesticides, herbicides, and production and maintenance of machinery. The total amount and distribution varies with farming system. These estimates are considered to be reasonable approximations. They are important because the rate at which energy can by produced in the form of biogas will be compared with the rate of energy expenditure on the farm in the form of fuel and electricity.

Additional energy is required for the raising of the pigs. These requirements are estimated to be 100000 and $34000 \mathrm{MJ} /$ year for the livestock operations and feed processing, respectively (Table 1 ). 
Table 1. Energy values ( $10^{9} \mathrm{~J} /$ year) of several products used and produced on a farm where pigs are raised from $50 \mathrm{~kg}$ to $100 \mathrm{~kg}$ per pig. There are 100 pigs at all times. The through-put is 560 pigs/year.

\begin{tabular}{|c|c|}
\hline Solar energy & \\
\hline Corn (12.41 ha) & \\
\hline grain (99295 kg/year) & 1877 \\
\hline straw (99 $280 \mathrm{~kg} /$ year $)$ & 1877 \\
\hline roots $(62050 \mathrm{~kg} /$ year $)$ & 1172 \\
\hline total & 4926 \\
\hline Soybeans (2.85 ha) & \\
\hline beans (meal) (7 $096 \mathrm{~kg} /$ year) & 134 \\
\hline beans (oil) (1 $454 \mathrm{~kg} /$ year) & 29 \\
\hline straw (9 $975 \mathrm{~kg} /$ year) & 189 \\
\hline roots $(5700 \mathrm{~kg} /$ year $)$ & 109 \\
\hline total & 461 \\
\hline Farming operations & \\
\hline cultural energy & 454 \\
\hline livestock housing and care & 101 \\
\hline feed processing & 34 \\
\hline Products & \\
\hline pork $(19600 \mathrm{~kg} /$ year $)$ & 248 \\
\hline biogas, no straw (7 $140 \mathrm{~m}^{3} /$ year) & 160 \\
\hline biogas with straw (22 $776 \mathrm{~m}^{3} /$ year) & 508 \\
\hline nitrogen $(1435 \mathrm{~kg} /$ year $)$ & 105 \\
\hline phosphorus (350 kg/year) & 4 \\
\hline potassium $(490 \mathrm{~kg} /$ year $)$ & 4 \\
\hline
\end{tabular}

\section{Yield of pork}

Our analysis is concerned with feeding groups of pigs from an initial weight of 50 $\mathrm{kg} / \mathrm{pig}$ to a final weight of $100 \mathrm{~kg} / \mathrm{pig}$. About $70 \%$ of the final weight is available for consumption. This percentage varies according to local customs. The yield of useful product is therefore $19600 \mathrm{~kg}$ /year. This represents $247000 \mathrm{MJ}$ of digestible energy assuming an average of $12.6 \mathrm{MJ} / \mathrm{kg}$ (ham 8.4 ; chop 11.3 ; fat roast 15.5 ; lean roast 10.9; links $20.2 \mathrm{MJ} / \mathrm{kg}$ ). The efficiency with which the total amount of solar energy captured by the plants is coverted to food energy is therefore $4.6 \%$. The digestible energy in the pork represents $12.3 \%$ of the combustible energy in the feed grain, $15.8 \%$ of the digestible energy in the feed, and $9.4 \%$ of the total energy input (Table 2).

\section{Manure}

The manure consists of the excrements, spilled feed, and bedding material. Here only excrements and $5 \%$ spilled feed are considered. The volume of discharge is 300 $\mathrm{l} /$ day with $14 \%(\mathrm{w} / \mathrm{w})$ solids or $42 \mathrm{~kg} /$ day. Additional information is in Fig. 1 . Use of bedding material could change characteristics substantially.

The protein digestibility of the feed is $75 \%$ so that the pigs excrete $0.25 \times$ 
Table 2. Energy inputs and outputs for a farming operation in which 100 pigs are raised from $50 \mathrm{~kg}$ to $100 \mathrm{~kg}$. The numbers shown pertain to a period of one year.

\begin{tabular}{|c|c|c|c|c|c|}
\hline \multirow[t]{2}{*}{ Category } & & \multicolumn{2}{|c|}{ No straw } & \multicolumn{2}{|c|}{ With straw } \\
\hline & & $\begin{array}{l}\text { energy } \\
\text { content } \\
\left(10^{9} \mathrm{~J}\right)\end{array}$ & $\begin{array}{l}\% \text { of } \\
\text { total } \\
\text { input }\end{array}$ & $\begin{array}{l}\text { energy } \\
\text { content } \\
\left(10^{9} \mathrm{~J}\right)\end{array}$ & $\begin{array}{l}\% \text { of } \\
\text { total } \\
\text { input }\end{array}$ \\
\hline \multicolumn{6}{|l|}{ Energy input } \\
\hline Corn grain & & 1877 & 72.2 & 1877 & 47.1 \\
\hline Soybeans & & 134 & 5.2 & 134 & 3.4 \\
\hline Straw & & - & - & 1386 & 34.8 \\
\hline \multicolumn{6}{|l|}{ Farming: } \\
\hline fuel \& electricity & 228 & & & & \\
\hline fertlizers & 136 & & & & \\
\hline labor \& machinery & 91 & & & & \\
\hline livestock maintenance & 101 & & & & \\
\hline \multirow[t]{2}{*}{ feed processing } & 34 & & & & \\
\hline & $\overline{590}$ & 590 & 22.6 & 590 & 14.8 \\
\hline Total & & $\overline{2601}$ & $\overline{100.0}$ & 3987 & 100.0 \\
\hline \multicolumn{6}{|c|}{ Energy output, useful products } \\
\hline Pork & & 248 & 9.4 & 248 & 6.2 \\
\hline Biogas & & 160 & 6.1 & 508 & 12.7 \\
\hline $\mathrm{N}$ & & 105 & 4.0 & 105 & 2.6 \\
\hline $\mathrm{P}$ & & 4 & 0.2 & 4 & 0.1 \\
\hline K & & 4 & 0.2 & 4 & 0.1 \\
\hline Total & & 521 & 19.8 & 869 & 21.7 \\
\hline \multicolumn{6}{|l|}{ Energy sinks } \\
\hline Heat loss from pigs & & 1092 & 41.6 & 1092 & 27.4 \\
\hline $\mathrm{CO}_{2}$ and other gases & & 504 & 19.2 & 1428 & 35.8 \\
\hline Other (e.g. fiber residue) & & 508 & 19.4 & 613 & 15.4 \\
\hline Total & & $\overline{2104}$ & $\overline{80.2}$ & 3133 & 78.6 \\
\hline
\end{tabular}

$36.5 / 6.25=1.5 \mathrm{~kg} \mathrm{~N} /$ day in the feces. Of the $27.4 \mathrm{~kg}$ of protein absorbed by the pigs, $53 \%$ is discharged in the urine, corresponding to a $\mathrm{N}$ loss of $27.4 \times 0.53 / 6.25$ $=2.3 \mathrm{~kg} /$ day. This $\mathrm{N}$ is mostly in the form of urea which is readily converted to ammonia by bacterial activity. The pigs may thus be expected to excrete a total of 3.8 $\mathrm{kg} \mathrm{N} /$ day. The spilled feed contains $0.3 \mathrm{~kg} \mathrm{~N} /$ day so that the manure contains a total of $4.1 \mathrm{~kg} \mathrm{~N} /$ day. The $\mathrm{N}$ is mostly in the ammonium form. The remainder is in dissolved organic matter and in suspended organic solids. The manure contains 1.0 $\mathrm{kg} \mathrm{P} /$ day and $1.4 \mathrm{~kg} \mathrm{~K} /$ day. The $\mathrm{C} / \mathrm{N}$ ratio is 9.8 .

\section{Methane and fertilizer}

\section{Process description}

The simplest method for recovery of useful products is to route all of the fresh man- 
ure into an anaerobic digester for the production of biogas and to solubilize plant nutrients.

The 300 liters fresh manure produced each day by the 100 pigs must be diluted with about 300 liters of water to make the suspension easier to pump and to reduce the concentration of total solids in the digester to about $7 \%(\mathrm{w} / \mathrm{w})$. A range of 7 to $9 \%$ is recommended for optimum operation of the digester. It may be necessary to dilute the manure more to avoid ammonia toxicity which occurs at concentrations of ammonia $\mathrm{N}$ above $1200 \mathrm{mg} / \mathrm{l}$ and to avoid production of volatile fatty acids in excess of $5.9 \mathrm{~kg} / \mathrm{m}^{3}$ per day.

The volume of dilution water is not sufficient to operate a gutter flushing system. The pigs must therefore be kept on slatted floors with the manure collecting in a pit below. The manure is mixed with water in the pit and then pumped into the anaerobic digester.

Optimum digestion is obtained with retention times of 10 to 17 days. The digester must be large enough to store the volume of manure produced during this period. The size is determined by the preferred volume of dilution water and retention time. For example, a retention time of 15 days and an inflow of $800 \mathrm{l}$ /day (300 liters manure with 500 liters dilution water) requires a volume of $12 \mathrm{~m}^{3}$. Continuous operation is accomplished by adding diluted manure each day and allowing an equal volume of digested waste to flow into a storage tank or holding pond.

\section{Product yields}

The manure discharged by the 100 pigs each day contains $34 \mathrm{~kg}$ of volatile solids (VS) (Meek et al., 1975). The amount depends on composition of feed, bedding material, and age of pigs. Half of the VS are destroyed by the anaerobic digestion process to yield $\mathrm{CH}_{4}$ and $\mathrm{CO}_{2}$. The efficiency of conversion depends on temperature, loading rate, and $\mathrm{pH}$. The digestion may be expected to yield from 1 to $1.4 \mathrm{~m}^{3}$ of biogas per $\mathrm{kg}$ of VS removed. Volumes of gas are reported at the standard temperature of $20^{\circ} \mathrm{C}$ and pressure of $101.3 \mathrm{kPa}$. The biogas contains usually about $60 \% \mathrm{CH}_{4}$ and $40 \% \mathrm{CO}_{2}$. The combustible energy of the mixture is about $22.3 \mathrm{MJ} / \mathrm{m}^{3}$.

The yield of biogas is $20.4 \mathrm{~m}^{3} /$ day, assuming $1.2 \mathrm{~m}^{3}$ of biogas per $\mathrm{kg}$ VS removed per day. The actual yield depends on loading rate, $\mathrm{pH}$, temperature, and retention time. Some of these variables may change substantially during the course of one year unless operating conditions are carefully controlled. The operator must have the flexibility in his management system to adjust to these changes.

The biogas recovers about $6.1 \%$ of the total amount of solar energy and cultural energy represented by the corn and soybean meal (Table 2). However, the recovery is equivalent to $70 \%$ of the energy used in farming operations.

The liquid outflow from the digester contains plant nutrients and is a good soil conditioner. All of the nutrients originally present in the manure are present in the digester outflow. The availability of the $\mathrm{N}$ to plants has been increased because of the decrease in carbon molecules which escaped as $\mathrm{CH}_{4}$ and $\mathrm{CO}_{2}$.

The daily outflow contains $25 \mathrm{~kg}$ of dry matter which consists of $12.5 \mathrm{~kg}$ of bacterial cells with a crude protein content of $50 \%, 7.2 \mathrm{~kg}$ of fiber residue, and $4.1 \mathrm{~kg}$ of $\mathrm{N}$ including $1.0 \mathrm{~kg}$ of organic $\mathrm{N}$ in the bacterial cells (Fig. 1). The fiber residues were 
not solubilized by the bacteria in the digester but can be utilized by fungi in the soil. On an annual basis the total outflow from the digester contains $1435 \mathrm{~kg} \mathrm{~N}, 350 \mathrm{~kg} \mathrm{P}$, and $490 \mathrm{~kg} \mathrm{~K}$. When spread on land, each ha of the 15.26 ha of land needed to raise the corn and soybean meal for the swine ration would receive $94 \mathrm{~kg} \mathrm{~N}, 23.0 \mathrm{~kg} \mathrm{P}$, and $32.0 \mathrm{~kg} \mathrm{~K}$ per year. The energy value of the recovered fertilizer represents $4.4 \%$ of the total energy input (Table 2).

The use of processed sludge as a feed supplement for ruminants merits consideration. The yield of crude protein is $2888 \mathrm{~kg} /$ year.

\section{Use of biogas}

Although it is possible to use the biogas as it comes from the digester, its value will be increased by removal of the carbon dioxide. Removal of the $\mathrm{CO}_{2}$ from the biogas increases the energy content from 22,3 tot $37.0 \mathrm{MJ} / \mathrm{m}^{3}$. The techniques most frequently used in chemical plants or gas fields for separation of $\mathrm{CO}_{2}$ from other gases are absorption in monoethanolamine or in hot potassium carbonate (Benfield process) at pressures of 1.42 to $3.45 \mathrm{MPa}$. These processes are economically feasible only at flow rates in excess of $200000 \mathrm{~m}^{3}$ /day. Adsorption of the $\mathrm{CO}_{2}$ on molecular sieves made of natural zeolite is being evaluated as a more economical separation process at low flow rates. Drying of the methane gas can be accomplished through contact with activated alumina, silica gel, or triethylene glycol.

Removal of $\mathrm{CO}_{2}$ and water from the biogas is necessary when the gas is injected into existing pipelines and used as a substitute for natural gas. When biogas is used on-site and on a small scale it may be more economical to modify equipment to burn the biogas as it comes from the digester.

The heating value of the $20.4 \mathrm{~m}^{3}$ of biogas is $456.7 \mathrm{MJ} /$ day. A well insulated home with three bedrooms and a heated space of $283 \mathrm{~m}^{3}$ requires an average of 260.4 $\mathrm{MJ} /$ day in Portland, Oregon, during January which has 791 degree days. The same house requires an average of $512.4 \mathrm{MJ} /$ day in Minneapolis, Minnesota, where January has 1562 degree days. If the biogas were used to generate electricity, it could produce $22 \mathrm{kWh} /$ day. The average use per household is about $23 \mathrm{kWh} /$ day for the US and about $43 \mathrm{kWh} /$ day for Oregon.

On farms, the biogas from the digester can be used for cooking, heating of water and buildings, refrigeration, or generation of electricity. Use for farm machinery does not seem to be practical. For example, a $73.5 \mathrm{~kW}$ tractor operating for 1 hour requires $45 \mathrm{~m}^{3}$ of biogas. The annual yield of $7140 \mathrm{~m}^{3}$ would allow the use of the tractor for 158.7 hours. This yield is promising in relation to the requirements for cultivation of the 12.41 ha of corn and 2.85 ha of soybeans needed to provide the feed for the 100 pigs.

However, a cylindrical fuel tank, $16 \mathrm{~m}$ long, with a diameter of $6 \mathrm{~m}$, is required to store $450 \mathrm{~m}^{3}$ of the biogas which would be sufficient to run a $73.5 \mathrm{~kW}$ tractor for 10 hours. Compressing the gas is therefore necessary. A standard sized fuel tank for a $73.5 \mathrm{~kW}$ tractor has a volume of $0.227 \mathrm{~m}^{3}$. Storage of the amount of biogas required to fuel the $73.5 \mathrm{~kW}$ tractor for 1 hour, namely $45 \mathrm{~m}^{3}$, in this volume at standard conditions would require a pressure of $20.8 \mathrm{MPa}$. If the pressure is reduced to a more manageable $2.1 \mathrm{MPa}$, the tractor would run for only $6 \mathrm{~min}$. 
The digestion process requires energy to heat and mix the contents of the digester, pump influent and effluent, and perhaps compress the gas for storage. The largest amount is needed for heating the digester and its contents. This heating requirement is determined by the outside temperature and the insulation used for the tank. Heating to $37^{\circ} \mathrm{C}$ and mixing are necessary to provide optimum conditions for the growth of the bacteria in the digester. Mixing is required for only a few minutes each day.

The performance of an anaerobic digester supplied with manure from 100 dairy cows was evaluated on a commercial scale by the A. O. Smith Co., Milwaukee, WI. An experimental digester with a volume of $120 \mathrm{~m}^{3}$ was operated for 18 months. The field installation consisted of a heated and mixed digester, a collection pit to receive fresh manure, a storage pit for the digester effluent until it could be spread on land, and a service building to house equipment and instruments. The digester was made from a grain silo with walls of glass-coated steel, insulated on the outside with $5.1 \mathrm{~cm}$ of polyurethane. The structure was above ground. The digester was heated at $35^{\circ} \mathrm{C}$ and mixed intermittently for a total of about 6 hours per day.

About $74 \%$ of the biogas was needed for heating the digester to $35^{\circ} \mathrm{C}$ during the coldest month when air temperatures averaged $-9^{\circ} \mathrm{C}$ and $26 \%$ during the warmest month when air temperatures averaged $24{ }^{\circ} \mathrm{C}$. The cost of producing the methane gas in excess of the heating requirements of the digester was estimated at $\$ 2.83$ to $\$ 3.31$ per $1000 \mathrm{MJ}$. This cost compared to $\$ 2.08$ per $1000 \mathrm{MJ}$ of natural gas for home heating in the Milwaukee, WI, area. The price of natural gas varies considerably throughout the USA. For example, the cost of natural gas for home heating in the Willamette Valley, Oregon, is $\$ 3.31$ per $1000 \mathrm{MJ}$. The cost of producing methane gas from animal manure is more favorable in geographic areas with mild temperatures or where heat from other sources is available to maintain digester temperatures.

\section{Increasing the yield of biogas}

The yield of biogas with a maximum energy content is highest at a $\mathrm{C} / \mathrm{N}$ ratio of about 30 . The yield of methane increases as the $\mathrm{C} / \mathrm{N}$ ratio approaches 30 , while the total yield of biogas remains fairly constant. The $\mathrm{C} / \mathrm{N}$ ratio of the swine manure used her was 9.8 (Fig. 1). The yield of gas can be increased by adding materials which contain a large cellulose content. Usually waste products such as straw or other crop residues are readily available for this purpose.

We calculated the amount of straw which should be added to the digester to increase the $\mathrm{C} / \mathrm{N}$ ratio from 9.8 to 30 . To obtain a $\mathrm{C} / \mathrm{N}$ ratio of $30,4.1 \times 30=123 \mathrm{~kg}$ $\mathrm{COD}^{1}$ per day should be added to the digester. Since $40.2 \mathrm{~kg}$ COD per day is in the manure, an additional $82.8 \mathrm{~kg}$ COD per day must be provided by another carbon source. The estimated yield of biogas is then $123 / 40.2=3.06$ times greater than without the COD added, or $62.4 \mathrm{~m}^{3} /$ day.

The straw or other material must supply sufficient carbon to yield $62.4-20.4=$

COD $=$ Chemical Oxygen Demand. 
$42.0 \mathrm{~m}^{3}$ biogas per day. Assume a mixture of $60 \% \mathrm{CH}_{4}$ and $40 \% \mathrm{CO}_{2}$ in the biogas. Assume further that straw is used which contains $64 \%(\mathrm{w} / \mathrm{w})$ of cellulose and hemicellulose with a digestibility of $45 \%$ and that the yield is $0.44 \mathrm{~m}^{3} \mathrm{CH}_{4}$ per kg of cellulose and hemicellulose (Han, Lee \& Anderson, 1975). The yield of $\mathrm{CH}_{4}$ per $\mathrm{kg}$ of straw is then $1 \times 0.64 \times 0.45 \times 0.44=0.127 \mathrm{~m}^{3} \mathrm{CH}_{4}$. The total yield increase is $42.0 \times 0.60=25.2 \mathrm{~m}^{3} \mathrm{CH}_{4}$. The total amount of straw to be added is $25.2 / 0.127=$ $200 \mathrm{~kg} /$ day or $200 \times 365=73000 \mathrm{~kg} /$ year. This amount is $67 \%$ of the straw left in the fields (Table 1) and can be harvested without detriment to the land.

By adding the straw the energy yield of the digester becomes $508000 \mathrm{MJ} /$ year or $12.7 \%$ of the total amount of solar energy and cultural energy represented by the corn, soybean meal, and straw (Table 2). The biogas energy is equivalent to $223 \%$ of the energy used in farming operations.

\section{Pre-treatment}

Pure cellulose is readily digested under anaerobic conditions. However, in its natural state it is chemically bound to hemicellulose and lignin in a complex structure which is largely inaccessible to the extracellular enzymes of the bacteria in the digester. Pretreatment of the waste is therefore necessary. The use of either strong acids or alkali, chemical pulping, steeping in hot water or steam, irradiation with high-energy electrons, enzymatic hydrolysis by wood-rot fungi, and mechanical grinding into fine particles have been investigated. Grinding in a ball mill is probably the most practical approach for small operations. It remains to be determined whether the increase in biogas production can justify the energy consumption of the grinding process.

\section{New designs for digesters}

The rate at which properly pretreated wastes can be added to the digester is limited by the kinetics of methane formation. Anaerobic digestion is a three-phase process with sequential biochemical reactions of hydrolysis, acidification, and methanation. Complex organic molecules such as cellulose, starch, proteins, and lipids are first hydrolysed by mixed populations of non-methanogenic bacteria into simpler soluble molecules such as glucose, peptides, amino acids, and long-chain fatty acids. The extracellular metabolic end products are primarily short chain fatty acids such as acetic, propionic and butyric acids, aldehydes, alcohols, hydrogen, and carbon dioxide. These serve as substrates for the growth of methanogenic populations of bacteria, which in turn generate their own extracellular end products, primarily methane and carbon dioxide.

The anaerobic digestion of organic wastes is thus mediated by two distinct groups of bacterial populations, which differ from each other in growth characteristics and sensitivity to environmental conditions. There is evidence that the methane producers are more sensitive to changes in temperature and $\mathrm{pH}$ than the acid producers, and that the rate limiting step in the process is the rate of formation of methane from the volatile fatty acids. For example, the loading rate of a well mixed, mesophilic digester is restricted to avoid the accumulation of volatile fatty acids in excess of $5.9 \mathrm{~kg} / \mathrm{m}^{3}$ per day or else the resulting drop in $\mathrm{pH}$ inhibits growth of the metha- 
nogenic bacteria. This limitation makes it necessary to operate digesters at long retention times, thereby increasing the size and thus capital and operating costs.

Separating the acidogenic and methanogenic populations of bacteria and permitting them to grow in separate reactors under environmental and nutritional conditions most suitable for each group, may optimize the process. Recent studies on twophase anaerobic digestion have been encouraging (Ghosh \& Klass, 1977). The maximum conversion of glucose to methane was found to require 4 hours for the acidphase and 4 days for the methane-phase digestion. The conversion of cellulose to methane was found to require more time, namely 1 to 2 days for the hydrolysis and acid-phase digestion and 5 to 8 days for the methane-phase digestion. Production rates and yields of methane were found to exceed those for conventional, singlephase digesters. Phase separation may thus be expected to provide substantial benefits including reduced digester volume and reduced costs of construction.

\section{Concluding remarks}

Some serious problems must be solved before acceptance of the use of digesters in combination with small livestock operations can be expected. One problem is the integration between the availability of the gas and the energy needs of the farming enterprise. The quantity of available gas may be expected to vary dramatically during the year as well as from year to year. Progressing through the year, the activity on the farm may range from having very few or only young animals present to a fully stocked herd of marketable animals. The quantity and quality of manure available for digestion varies correspondingly. More importantly, it may be advantageous to have no pigs at all during certain years. The fluctuating level of availability poses limitations on the uses which can be made of the gas. These problems are in part mediated by making the use of straw an important part of the process.

The energy needs of many applications vary during the year, and so does the availability of the gas. The situation where energy needs and gas availability are matched will be a very fortuitous circumstance which may never occur unless special operating procedures are carefully worked out and strictly adhered to. The use of the gas may be enhanced by converting it to an energy form which can be more easily stored. Better continuity may also be achieved by feeding the digester with materials other than the manure. Much of the straw left on fields presents a readily available source of such materials.

An important research need is the development of management systems which are specially aimed at the full utilization of all resources available to the farmer. We suggest that problems to be investigated include those of finding means to store the gas for later use, transformation of the gas to a form of energy which can be stored and transported, the development of uses for the gas which lead to products that can easily be sold by the farmer, increase of gas production through the addition of cellulosic waste products, and finally improvement in the digestion process itself. 


\section{References}

Boersma, L., E. Gasper, J. R. Miner, J. E. Oldfield, H. K. Phinney \& P. R. Cheeke, 1978. Management of swine manure for the recovery of protein and biogas. Special Report No. 507, Agricultural Experiment Station, Oregon State University, Corvallis, OR.

Ghos, S. \& D. L. Klass, 1977. Two-phase anaerobic digestion. In: Clean fuels from biomass and wastes. Proceedings of symposium (25-28 January, Orlando, Florida): 374-415. Institute of Gas Technology, Chicago, Illinois, $521 \mathrm{pp}$.

Han, Y. M., J. S. Lee \& A. W. Anderson, 1975. Chemical composition and digestibility of ryegrass straw. J. Agric. Food Chem. 23: 928-931.

Meek, B., L. Chesnin, W. Fuller, R. Miller \& D. Turner, 1975. Guidelines for manure use and disposal in the Western Region, USA. Bull. Coll. Agric. Res. Center, Wash. St. Univ., Pullman No. 814; 18 pp.

Pimentel, D., L. E. Hurd, A. C. Bellotti, M. J. Forster, I. N. Oka, D. D. Sholes \& R. J. Whitman, 1974. Food production and the energy crisis. Science 182: 443-449. 